\title{
LYSANDA PASTE: A NEW OPTION FOR ROOT-END FILLING
}

\section{Norberti BERNARDINELI ${ }^{1}$, Clovis Monteiro BRAMANTE ${ }^{1}$, Ivaldo Gomes de MORAES ${ }^{2}$, Roberto Brandão GARCIA ${ }^{3}$}

\author{
1- PhD, Professor, Department of Dentistry, Endodontics and Dental Materials, Bauru School of Dentistry, University of São Paulo, Bauru, SP, \\ Brazil. \\ 2- PhD, Associate Professor, Department of Dentistry, Endodontics and Dental Materials, Bauru School of Dentistry, University of São Paulo, \\ Bauru, SP, Brazil. \\ 3- PhD, Assistant Professor, Department of Dentistry, Endodontics and Dental Materials, Bauru School of Dentistry, University of São Paulo, \\ Bauru, SP, Brazil.
}

Corresponding address: Prof. Dr. Norberti Bernardineli - Departamento de Dentística Endodontia e Materiais Dentários - Al. Octávio Pinheiro Brisola, 9-75 - Vila Universitária - 17012-901 Bauru, SP, Brasil - Phone: +55 (14) 3235-8344 - Fax +55 (14) $3224-2788$

e-mail: norberti@fob.usp.br or srbettio@fob.usp.br

Received: April 03, 2007 - Modification: July 23, 2007 - Accepted: August 08, 2007

\begin{abstract}
$\Gamma_{\text {his }}$

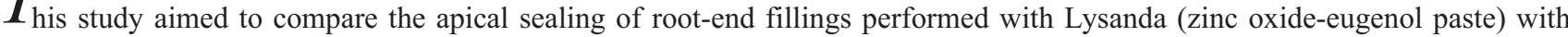
radiopacifiers (iodoform or zinc oxide) and calcium hydroxide. Root-end cavities were prepared and filled with different materials, as follows: Group I - Lysanda paste with iodoform; Group II - Lysanda paste with iodoform and calcium hydroxide; Group III - Lysanda paste with iodoform and zinc oxide; Group IV - Lysanda paste with zinc oxide; Group V - mineral trioxide aggregate (MTA). After filling, the teeth were immersed in 2\% methylene blue for analysis of marginal leakage. It was observed that marginal leakage occurred in all groups. Lysanda paste with iodoform showed the lowest leakage, with no statistically significant difference compared to the other groups. All materials can be considered as good options for root-end filling.
\end{abstract}

Uniterms: Root canal filling materials; Lysanda paste; Dental leakage.

\section{INTRODUCTION}

Endodontic surgery is an acceptable procedure in cases of failure of endodontic treatment $t^{5,12}$.

Root-end filling is the most used surgical treatment. Root-end filling materials play an important role due to their physical, chemical and biological properties. Several materials have been suggested for root-end filling, including amalgam $^{1}$, zinc oxide ${ }^{19}, \mathrm{IRM}^{9,13}$, composite resin ${ }^{15,22}$, EBA $^{1,14,20}$, polycarboxylate cement ${ }^{16}$, Sealer $26^{24}$, Sealape ${ }^{24,}$ hydroxyapatite ${ }^{14}$, VERRM $^{8}$ and, more recently, MTA $^{1,2,6,13,17,23,25,26}$.

Lysanda is a zinc oxide-eugenol material presented in two pastes; it is widely used in Prosthodontics. Dutra and Horta $^{11}$ (1994), Custodio and Costa ${ }^{7}$ (1994) and Bernardineli ${ }^{3}$ (1995) used this materials for root-end filling with good results and excellent adaptation to the cavity walls. Morais ${ }^{18}$ (2003) studied the reaction of rat subcutaneous connective tissue to Lysanda paste, MTA and Portland cement containing iodoform and observed that Lysanda paste caused significantly lower inflammatory reaction than MTA and Portland cement, including formation of a more organized fibrous capsule compared to the other two groups.
Root-end filling materials require radiopacity to allow better radiographic visualization. Bismuth oxide, barium sulfate, zinc oxide and iodoform are radiopacifiers used in Endodontics and root-end filling materials ${ }^{4,6,10,21}$. Since Lysanda paste does not show this characteristic, it is important to determine whether the presence of these substances (zinc oxide or iodoform) would alter the properties of this paste and influence the apical marginal sealing of root-end fillings.

\section{MATERIALAND METHODS}

The root canals of 50 single-rooted teeth from the tooth bank of the Department of Restorative Dentistry, Endodontics and Dental Materials, Dental School of Bauru were instrumented by the stepback technique, irrigated with saline, dried with absorbent paper points and filled with gutta-percha, zinc oxide and eugenol by the lateral condensation technique.

The apices were cut into approximately $2 \mathrm{~mm}$ at $45^{\circ}$ with a \#699 tapered bur in a buccal direction. The teeth were rendered impermeable by application of fast-setting Araldite 
and nail varnish. Apical cavities were prepared to a depth of $2 \mathrm{~mm}$ with \#2 round bur, complemented by irrigation with saline. The teeth were randomly divided into five groups of 10 teeth each and submitted to root-end filling with the following test materials: Group I - Lysanda paste with iodoform; Group II - Lysanda paste with iodoform and calcium hydroxide; Group III - Lysanda paste with iodoform and zinc oxide; Group IV -Lysanda paste with zinc oxide; and Group V - MTA.

In Group I, $0.62 \mathrm{~g}$ of red Lysanda paste and $0.46 \mathrm{~g}$ of white Lysanda paste were placed on a plate, with addition of $0.22 \mathrm{~g}$ of iodoform, and were mixed for $30 \mathrm{~s}$. The material was then inserted in the root-end cavity with a blunt-tip probe until complete filling. Excess material was immediately removed. Procedures for Group II were the same as performed for Group I, with addition of $0.22 \mathrm{~g}$ of iodoform and $0.11 \mathrm{~g}$ of calcium hydroxide. In Group III, the procedures were the same as those for Group I, with addition of $0.11 \mathrm{~g}$ of iodoform and $0.11 \mathrm{~g}$ of zinc oxide. In Group IV, the procedures were the same as for Group I, with addition of $0.22 \mathrm{~g}$ of zinc oxide. In Group V, MTA was prepared by mixing the power with distilled water until the ideal consistency for root-end filling was obtained.

After root-end filling, the teeth were immediately immersed in $2 \%$ aqueous methylene blue solution and incubated for 24 hours in an oven at $37^{\circ} \mathrm{C}$ in humid environment, with a small container with water.

Then, the teeth were removed from the dye and sectioned buccolingually with a diamond disc, until half of root canal filling and consequently the root-end filling were exposed. This area was analyzed by reflected light microscopy for determination of leakage at buccolingual interfaces, in millimeters.

Data were statistically analyzed by one-way analysis of variance to investigate the possible significant differences between groups.

\section{RESULTS}

Table 1 shows the means and standard deviations of apical leakage observed for the experimental groups, namely $0.44 \mathrm{~mm}$ for Group I (Lysanda + iodoform), $0.46 \mathrm{~mm}$ for Group II (Lysanda + iodoform + calcium hydroxide), $0.48 \mathrm{~mm}$ for Group V(MTA), $0.68 \mathrm{~mm}$ for Group IV (Lysanda + zinc oxide), and $0.77 \mathrm{~mm}$ for Group III (Lysanda + iodoform + zinc oxide).

One-way analysis of variance showed no significant differences in apical leakage between the different experimental groups (Table 2).

\section{DISCUSSION}

In the present study, there were no differences in apical leakage between groups. Lysanda paste yielded similar results as the other groups, regardless of the substances added (Table 1).

Dutra and Horta ${ }^{11}$ (1994) analyzing root-end fillings in dog's teeth, confirmed the high effectiveness of Lysanda paste compared to amalgam. Custódio and $\operatorname{Costa}^{7}$ (1994) investigated the marginal leakage of root-end fillings with Lysanda, amalgam, ionomer and resin, and observed significantly better results for Lysanda. This is in agreement with the present results, including the observation of excellent adaptation of Lysanda paste with its components and of MTA.

The addition of other materials to Lysanda paste also provided satisfactory results, as shown by the numerical differences that yet were not statistically significant. The highest leakage rates, without statistical difference, were observed for Groups III and IV, which contained zinc oxide, probably due to lack of affinity between its components.

Analysis of Table 1 shows that the lowest leakage occurred in Group I (Lysanda with iodoform), without statistically significant difference compared to MTA.

According to Bramante and Berbert ${ }^{5}$ (2000), four aspects are important for the success of root-end filling: the employed material, including its adequate physical, chemical and biological characteristics, is probably the most important factor. As mentioned earlier, numerous materials have been tested for root-end filling, all of which have advantages and disadvantages, yet certainly without meeting all or most requirements for good sealing.

With respect to Lysanda paste, one of the first studies using this material for root-end filling was conducted by Bernardineli $^{3}$ (1995), who demonstrated its high sealing

TABLE 1- Means (in $\mathrm{mm}$ ) and standard deviations ( $\pm \mathrm{SD}$ ) of apical leakage observed for the different experimental groups

\begin{tabular}{ll}
\hline Groups & Means (SD) \\
\hline Group I & $0.44(0.249769)$ \\
Group II & $0.46(0.336624)$ \\
Group III & $0.77(0.618317)$ \\
Group IV & $0.68(0.376670)$ \\
Group V & $0.48(0.274066)$
\end{tabular}

TABLE 2- Comparison of apical leakage between experimental groups by one-way analysis of variance (ANOVA)

\begin{tabular}{llllll}
\hline df & ms effect & df & ms error & F & p \\
\hline 4 & 0.223225 & 45 & 0.155002 & 1.440143 & $0.236364-\mathrm{ns}$ \\
\hline
\end{tabular}

$\mathrm{df}=$ degrees of freedom; $\mathrm{ns}=$ non-significant; $\mathrm{ms}=$ mean square 
ability and excellent adaptation to the cavity walls, especially when compared to other materials.

These data indicate the possible application of Lysanda paste as a new root-end filling material. However, the addition of radiopaque substances was needed to better test this material. In this respect, zinc oxide, calcium hydroxide and iodoform, either alone or in combination, seemed to be the ideal substances for this purpose, due to their good biocompatibility and broad clinical applicability. The advantages of iodoform as an intracanal medication include the formation of granulation tissue, new bone formation and lesion repair, leading to indication of its use. Zinc oxide and calcium hydroxide also show broad clinical applicability and their biological effects are widely known.

Another important aspect is the biocompatibility of Lysanda paste; its good acceptance is mainly related to the clinical indications of the material itself.

Morais $^{18}$ (2003), evaluating the reaction of rat subcutaneous connective tissue to MTA, Portland cement with iodoform and Lysanda paste, observed no difference between materials at 7 and 30 days, while at 60 days Lysanda paste showed significantly less inflammatory reaction than the other two cements. Portland cement with iodoform induced an even more organized fibrous capsule than MTA. An interesting aspect reported by Morais ${ }^{18}$ (2003) is that the use of iodoform with Portland cement, whose combination with other cements is poorly known, yielded satisfactory results when compared to Lysanda and even to MTA, somehow agreeing with the present results observed for addition of iodoform to Lysanda paste.

Conversely, in our opinion, the use of Lysanda paste is encouraging, even though its indication in dentistry has always been limited. In this context, a very important aspect is its low cost, in contrast to MTA, which has a relatively high cost. The combination of Lysanda with other substances was necessary to complement some of its properties, as required for clinical application.

All these observations suggest that MTA may still be indicated for root-end filling. Lysanda paste with iodoform yielded the best result and thus can also be considered a good option as root-end filling material, as demonstrated by its positive aspects observed in the present experiment and in previous studies.

Studies using Lysanda paste are limited, but the definitely promising results encourage further investigations, especially on its biological properties, to confirm its qualities as a root-end filling material and as a possible paste or cement for root canal filling in the future.

\section{CONCLUSIONS}

Overall, the analysis of the results allowed the following conclusions: 1. Apical marginal leakage occurred in all groups; 2. Lysanda paste with iodoform showed the lowest leakage, without statistically significant difference compared to other groups; 3. All materials can also be considered good options as root-end filling materials.

\section{ACKNOWLEDGMENTS}

The authors thank CNPq for the financial support and Prof. PhD José Roberto Pereira Lauris for the statistical analysis.

\section{REFERENCES}

1-Back SH, Plink H Junior, Kim S. Periapical tissue responses and cementum regeneration with amalgam, Super EBA and MTA as rootend filling materials. J Endod. 2005;31(6) 444-9.

2- Bates CF, Carnes DL, del Rio CE. Longitudinal sealing ability of mineral trioxide aggregate as a root end filling material. J Endod. 1996;22(11):575-8

3-Bernardineli N. Obturação retrógrada: avaliação ao MEV da adaptação às paredes das cavidades e infiltração marginal em função de materiais obturadores e de agentes de limpeza. Rev Fac Odontol Bauru. 1995;3(1/4):147-55.

4-Bortoluzzi EA, Broon NJ, Bramante CM, Garcia RB, Moraes IG, Bernardineli N. Sealing ability of MTA and radiopaque Portland Cement with or without calcium chloride for root-end filling. J Endod. 2006;32(9):897-900.

5-Bramante CM, Berbert A. Cirurgia parendodôntica. São Paulo: Ed. Santos; 2000.

6-Camilleri J, Pitt Ford TR. Mineral trioxide aggregate: a review of the constituents and biological properties of the material. Int Endod J. 2006;39(10):747-54.

7-Custódio AL, Costa, NP. Avaliação do vedamento apical de quatro materiais odontológicos utilizados em obturações retrógradas. Rev Odonto Cienc. 1994;9(18):35-48

8-Chng HK, Yap AUJ, Tong YW, Koh ET. Properties of a new root end filling material. J Endod. 2005;31(9):665-8.

9-Chong BS, PittFord TR, Hudston MB. A prospective clinical study of Mineral Trióxide Aggregate and IRM when used as root end filling materials in endodontic surgery. Int Endod J. 2003;36(8):520-6.

10-Coomaraswamy KS, Lumley PJ, Hofmann MP. Effect of bismuth oxide radioopacifier contend on the material properties of an endodontic Portland cement-based (MTA-like) system. J Endod. 2007;33 (3):295-8.

11-Dutra CEA, Horta HGP. Estudo da capacidade de vedamento da pasta Lysanda em obturações retrógradas: estudo em cães. Rev Odonto Cienc. 1994;9(8):7-21.

12-Kim S, Kratchman S. Modern endodontic surgery concepts and practice: a review. J Endod. 2006;32(7):601-23.

13-Lindeboom JAH, Frenken JWFH, Kroon FHM, Akker HP. A comparative prospective randomized clinical study of MTA and IRM as root-end filling materials in single-rooted teeth in endodontic surgery. Oral Surg Oral Med Oral Pathol Oral Radiol Endod. 2005;100(4):495-500

14-Mangin C, Yesilsoy C, Nissan R, Stevens R. A comparative sealing ability of hydroxyapatite cement, Mineral Trióxide Aggregate and super ethoxybenzoic acid as root end filling materials. J Endod. $2003 ; 28(4): 261-4$.

15-Mc Donald N, Dunsha TC. A comparative retrofill leakage study utilizing a dentin bonding material. J Endod. 1987;13(5):224-7. 
16-Mc Lean JW. A five year case history of a polycarboxylate cement root filling. J Br Endod Soc. 1971;5(2):20.

17-Montellano AM, Schwartz SA, Beeson TJ. Contamination of tooth-colored Mineral Trioxide Aggregate used as a root-end filling material: a bacterial leakage study. J Endod. 2006;32(5):452-5.

18-Morais CAH. Avaliação microscópica da reação do tecido conjuntivo subcutâneo de ratos à implantação dos cimentos MTA (Pro Root), Portland com iodofórmio e pasta Lysanda [tese]. Bauru (SP): Faculdade de Odontologia de Bauru, Universidade de São Paulo; 2003.

19-Nicholls E. Retrograde filling of the root canal. Oral Surg Oral Med Oral Pathol Oral Radiol. 1962;15(4):463-73.

20-Oynick J, Oynick T. A study of a new material for retrograde filling. J Endod. 1978;4(7):203-6.

21-Pinheiro Daniel RLD, Jaeger MMM, Lima Machado ME. Emprego do iodofórmio em endodontia. RPG Rev Pos-Grad. 1999;6(2):1759 .

22-Rud J, Rud V, Munksgaaard EC. Periapical healing of mandibular molar after root end sealing with dentine bonded composites. Int Endod J. 2001;34(4):285-92

23-Shahi S, Rahimi S, Lotfi M, Yavari HR, Gaderian AR. A Comparative study of the biocompatibility of three root-end filling materials in rat connectivet tissue. J Endod. 2006;32(8):776-80

24-Tanomaru M Filho, Marcone RL, Leonardo MR, Tanomaru JMG Silva LAB. Evaluation of periapical repair following retrograde filling with different root-end filling materials in dog teeth with periapical lesions. Oral Surg Oral Med Oral Pathol Oral Radiol Endod. 2006;102(1):127-32.

25- Torabinejad M, Pitt Ford TR, McKendry DJ, Abedi HR, Miller DA, Kariyawasam SP. Histologic assessment of Mineral Trioxide Aggregate as a root end filling in monkeys. J Endod. 1997;23(4):2258 .

26-Torabinejad M, PittFord TR. Root-end filling materials: a review. Endod Dent Traumatol. 1996;12:161-78. 